\title{
Sero-prevalence of human T-lymphotrophic virus 1/2 among HIV-1 infected individuals in Ilorin, Nigeria
}

\author{
${ }^{1}$ Adeoye, O. A., ${ }^{* 1}$ Ashaka, O. S., ${ }^{1}$ Omoare, A. A., ${ }^{2}$ Fawibe, A. E., and ${ }^{1}$ Agbede, O. O. \\ ${ }^{1}$ Department of Medical Microbiology and Parasitology, University of Ilorin, Ilorin, Nigeria \\ ${ }^{2}$ Department of Medicine, University of Ilorin, Ilorin, Nigeria \\ *Correspondence to: ashakseyi@gmail.com
}

\begin{abstract}
:
Background: HTLV-1 or 2 co-infection in individuals infected with HIV-1 can lead to increased morbidity. The shared routes of transmission of HTLV with HIV-1 may increase the prevalence of HTLV among HIV-1 infected population and subsequently affect patient's management.

Methods: Sera were collected from 144 HIV-1 infected individuals attending the highly active anti-retroviral therapy (HAART) clinic of the University of Ilorin Teaching Hospital between the months of May and August 2016. Sera were tested for anti-HTLV IgM and IgG antibodies to HTLV$1 \& 2$ using the sandwich enzyme-linked immunosorbent assay.

Results: Out of the 144 participants tested, 47 (32.6\%) and 37 (25.7\%) were positive for HTLV IgG and IgM respectively. Twenty-one participants $(14.6 \%)$ had both IgG and IgM antibodies to HTLV-1\&2. Ten individuals were anti-retroviral drug naïve out of which, four and six were positive to anti-HTLV IgG and IgM respectively.

Conclusion: Findings from this study revealed that there is high sero-prevalence of HTLV IgG and IgM antibodies among HIV-1 sero-positive individuals in Ilorin. The high rate of co-infection supports routine screening for HTLV-1/2 co-infection among HIV-1 infected individuals in Ilorin, Nigeria so that the purpose of HAART treatment and monitoring of patients to prevent progression to AIDS will not be aborted.
\end{abstract}

Keywords: Human T-cell lymphotrophic Virus, Human immunodeficiency virus-1, IgG, IgM, CD4+ counts

Received March 20, 2018; Revised March 20, 2019; Accepted March 23, 2019

Copyright 2019 AJCEM Open Access. This article is licensed and distributed under the terms of the Creative Commons Attrition 4.0 International License (http://creativecommmons.org/licenses/by/4.0), which permits unrestricted use, distribution and reproduction in any medium, provided credit is given to the original author(s) and the source.

\section{Prévalence sérologique du virus T-lymphotrophe humain $1 / 2$ chez les personnes infectées par le VIH-1 à Ilorin, au Nigéria}

\author{
${ }^{1}$ Adeoye, O. A., ${ }^{* 1}$ Ashaka, O. S., ${ }^{1}$ Omoare, A. A., ${ }^{2}$ Fawibe, A. E., and ${ }^{1}$ Agbede, 0.0. \\ ${ }^{1}$ Département de microbiologie médicale et de parasitologie, Université d'Ilorin, Ilorin, Nigéria \\ ${ }^{2}$ Département de médecine, Université d'Ilorin, Ilorin, Nigéria \\ *Correspondance à: ashakseyi@gmail.com
}

\begin{abstract}
Abstrait:
Contexte: La co-infection par le HTLV-1 ou 2 chez les personnes infectées par le VIH-1 peut entraîner une morbidité accrue. Les voies de transmission partagées du VIH-1 par le VIH-1 peuvent augmenter la prévalence du virus dans les populations infectées par le VIH-1 et, par conséquent, affecter la prise en charge du patient.

Méthodes: Des sérums ont été recueillis auprès de 144 personnes infectées par le VIH-1 fréquentant la clinique de traitement antirétroviral hautement actif (HAART) de I'hôpital
\end{abstract}


universitaire de Ilorin entre mai et août 2016. Les sérums ont été testés pour la détection des IgM et IgG anti-HTLV. anticorps anti-HTLV-1 et 2 en utilisant l'essai sandwich immuno-absorbant lié à une enzyme.

Résultats: Sur les 144 participants testés, $47(32,6 \%)$ et $37(25,7 \%)$ étaient positifs pour les IgG et les IgM du HTLV, respectivement. Vingt et un participants (14,6\%) avaient à la fois des anticorps IgG et IgM anti-HTLV-1 et 2 . Dix personnes n'avaient jamais reçu d'antirétroviraux, dont quatre et six étaient positives aux IgG et aux IgM anti-HTLV, respectivement.

Conclusion: Les résultats de cette étude ont révélé une prévalence élevée de l'anticorps IgG et IgM du HTLV chez les sujets séropositifs pour le VIH-1 à Ilorin. Le taux élevé de coïnfection favorise le dépistage systématique de la co-infection par HTLV - 1/2 chez les personnes infectées par le VIH - 1 à Ilorin, au Nigéria, de sorte que l'objectif du traitement HAART et du suivi des patients pour prévenir la progression du sida ne soit pas avorté.

Mots-clés: Virus lymphotrophe humain à cellules T, Virus de l'immunodéficience humaine-1, IgG, IgM, Compte de CD4+

\section{Introduction:}

Human T-lymphotrophic viruses (HTLV) and human immunodeficiency viruses (HIV-1) are two distinct family members of Retroviridae causing significant infections worldwide. These viruses have common modes of transmission and share an in vivo tropism for cells of the immune system particularly $\mathrm{T}$ lymphocytes, resulting into co-infections of a number of individuals worldwide $(1,2)$. HTLV is made up of two major types associated with disease in humans which are HTLV-1 and HTLV2. Two other types have been discovered which are HTLV-3 and HTLV4 (3). HTLV-1 is endemic in many welldefined geographic areas like SubSaharan Africa in which Nigeria is included. However, there is no recent representative data regarding prevalence of HTLV-1 among HIV-1 infected individuals in Nigeria but majority of serological studies carried out were on blood donors (4-8). Research has shown that HIV-1/HTLV-1 and HIV-1/HTLV-2 co-infection probably occur more frequently than physicians are aware of since routine testing for HTLV-1/2 is not usually performed.

HIV-1 infection is sexually transmitted therefore people with HIV-1 disease are at risk of having HTLV infection because both have same routes of transmission and similar cell tropism. Therefore, co-infection of both viruses will likely influence the pattern of progression to AIDS, since both viruses preferentially infect CD4+ T-cells. The common link between HTLV-1/2 in HIV1 patients is that both have been linked normal or high CD4+ T cell count hinder proper treatment as a result of delay in introduction of highly active antiretroviral therapy (HAART) in coinfected patients. It has also been reported that co-infection of HTLV-1/2 and HIV-1, may accelerate progression to AIDS and significantly shorten survival time in such individual (9).

A major issue in developing countries including Nigeria is lack of routine screening practice for HTLV, thus there exist gaps in knowledge and awareness of transmission of HTLV infection from both healthy individuals and those who are co-infected with HIV1. Little is known about the pattern of sero-prevalence of HTLV-1 in Ilorin; this study is therefore designed to determine the sero-prevalence of HTLV-1 among HIV-1 infected individuals attending the HAART clinic of UITH, Ilorin

\section{Materials and method:}

\section{Study design and participants}

This descriptive cross-sectional study was conducted at the HAART clinic among HIV-1 positive patients 18 years and above that visited University of Ilorin Teaching Hospital (UITH), Ilorin, Kwara State, Nigeria. At the HAART clinic, diagnoses of new cases of HIV infection are made and over 4000 HIV1/AIDS patients on therapy are monitored.

\section{Sample size determination}

Sample size was estimated using fisher's formula (10) adopting a prevalence rate of $10.47 \%$ (11) as follows; $N=Z^{2} p q / d^{2}$ where ' $N$ ' is the required sample size, ' $Z$ ' is the 
confidence interval at $95 \%(1.96)$, ' $p$ ' is estimated prevalence of HIV-1 Infection, ' $q$ ' is $1-p$, and ' $d$ ' is the degree of accuracy set at 0.05 . This gives a sample size of 144 . Patients were consecutively recruited after giving informed consents. Under aseptic conditions, $5 \mathrm{ml}$ of venous blood was collected from each consenting participant using a hypodermic needle. Aliquots of blood specimen were decanted into tubes without anticoagulant and EDTA anti-coagulated tubes to determine the CD4 count. The blood sample bottles were labeled with sample code L001- L144.

Serum from blood samples in tubes without anticoagulant were separated by allowing the blood to clot at room temperature, and then centrifuged at $2500 \mathrm{rpm}$ for 10 minutes. The serum samples were transferred into cryovials and stored at $-20{ }^{\circ} \mathrm{C}$ until required for analysis. The serum samples were analyzed for IgM and IgG antibodies to HTLV using enzyme-linked immunosorbent assay based on manufacturer's instruction.

Determination of CD4+ $\mathbf{T}$-cell count in peripheral blood of HIV-1 patients The CD4 T-cell count enumeration was done within 6 hours of blood specimen collection in HAART clinic laboratory in UITH. The blood sample dispensed inside the EDTA anticoagulated tubes was used to determine the CD4 T-cell count in whole blood using Partec Cytoflow analyser (12).

\section{Determination of anti-HTLV IgM and IgG antibodies in serum of HIV-1 patients} Analysis of IgG and IgM

Antibodies to HTLV were detected using human T-lymphotrophic virus sandwich ELISA. The micro-ELISA strip plates were pre-coated with an antigen specific to HTLV IgG and IgM antibodies respectively. Standards test samples were added to appropriate micro-ELISA strip plate wells and combined to specific antigen. Then a horseradish peroxidase (HRP)-conjugated antigen specific to HTLV was added to each micro-ELISA strip plate well and incubated. Free components were washed away. The TetraMethylBenzidine (TMB) contained HTLV substrate solution was added to each well. Only those wells that contained HTLV-IgG or IgM in different micro-ELISA strip plate respectively and HRP conjugate HTLV antigen appeared blue in colour and then yellow after addition of the stop solution. The optical density (O.D) was measured using a spectrophotometer at a wavelength of $450 \mathrm{~nm}$. The presence of anti-HTLV IgG or IgM antibodies in different microELISA strip plate, respectively, was determined by comparing the O.D of sample to CUT OFF value of the plate according to manufacturers' instruction.

\section{Statistical analysis}

Data entry and analysis was carried out using the Epi info version 7.14 (2014) software packages (CDC). Results were presented in tables and charts. Chi-square test was used for statistical significance of the difference for different variables respectively. $p$ value of $<0.05$ was regarded as significant.

\section{Ethical Considerations}

This study was conducted in compliance with the Helsinki Declaration of 1975, as revised in 2008 and was approved by the Health Research and Ethics Committee of the University of Ilorin Teaching Hospital (ERC PAN/2016/04/1532). The participants gave their written informed consent before they were enrolled in the study. All data were analyzed anonymously throughout the study.

\section{Results:}

A prevalence of 47 (32.6\%) and $37(25.7 \%)$ was reported for IgM and IgG antibodies to HTLV respectively in the study population. The prevalence of anti-HTLV IgG and IgM antibodies among HIV-1 patients in different age groups showed that more individuals within age group of 40-49 years had more anti-HTLV IgG and IgM antibodies as shown in Figure 1.

Both IgG and IgM antibodies to HTLV were detected together in 21 HIV1 patients among the different age groups. Among those between 30-39 years, six individuals had both IgG and IgM antibodies to HTLV, while among 
age group 40-49 years, 10 individuals had both IgG and IgM antibodies to HTLV, and also among age group 50-59 years, three individuals had both IgG and IgM antibodies to HTLV and in the age group greater than 60 years, two persons had both IgG and IgM antibodies to HTLV. Of the 144 HIV-1 seropositive patients recruited in this study, $40(27.8 \%)$ were males and 104 $(72.2 \%)$ were females. The females recruited in the study had HTLV IgG and IgM antibody than the males as shown in Table 1.



Figure 1: Frequency of anti-HTLV IgG/IgM antibodies among HIV-1 patients by age groups

Table 1: Gender distribution of HTLV IgG/IgM antibodies among HIV-1 seropositive patients at UITH

\begin{tabular}{ccccc}
\hline Gender & $\begin{array}{c}\text { Total } \\
\mathrm{N}(\%)\end{array}$ & $\begin{array}{c}\mathrm{IgG}+ \\
\mathrm{N}(\%)\end{array}$ & $\begin{array}{c}\mathrm{IgM}+ \\
\mathrm{N}(\%)\end{array}$ & $\begin{array}{c}\text { IgG+ IgM+ } \\
\mathrm{N}(\%)\end{array}$ \\
\hline Male & 40 & $12(30)$ & $9(22.5)$ & 4 \\
Female & 104 & $35(33.7)$ & $28(26.9)$ & 17 \\
Chi-square & & 0.175 & 0.296 & \\
$p$ value & & 0.675 & 0.586 & \\
Total & 144 & $47(32.6)$ & $37(25.7)$ & 21 \\
\hline
\end{tabular}


The distribution of HTLV IgG and IgM Antibodies by CD4 grouping among HIV-1 seropositive patients at UITH revealed that a number of participants with CD4 cell count below 200 cell $/ \mathrm{mm}^{3}$ had IgG and IgM antibodies to HTLV but with a low frequency while individuals whose CD4 cell count was above 200 cell $/ \mathrm{mm}^{3}$, had a high possibility of producing detectable IgG and IgM antibodies to HTLV. The CD4+ T-cell count of individuals that IgM antibodies to HTLV has been detected when compared to individuals not infected with HTLV is not significant as shown in Table 2.

Table 2: Distribution of HTLV IIG and IgM antibodies by CD4 grouping among HIV-1 seropositive patients at UTTH

\begin{tabular}{cccc}
\hline CD4 grouping & Total & \%olgGt & \%:gMt \\
& & & \\
\hline$\leq 200$ & 40 & $9(22.5)$ & $7(17.5)$ \\
$>200$ & 104 & $38(36.5)$ & $30(28.8)$ \\
Chi-square & & 2.589 & 1.948 \\
p-value & & 0.108 & 0.163 \\
Total & 144 & $47(32.6)$ & $37(25.7)$ \\
\hline
\end{tabular}

Table 3 shows sero-prevalence of HTLV IgG and IgM antibodies among HIV-1 sero-positive patients by ART status. Participants not on ART but seropositive for HTLV IgG are more than those not on ART but sero-positive for HTLV IgM.

Table 3: Sero-prevalence of HTLV infection among HIV-1 seropositive individuals by ART drug status

\begin{tabular}{cccc}
\hline HAART drugs & Total & IgGt $(\%)$ & IgMt $(\%)$ \\
\hline Yes & 134 & $41(30.6)$ & $33(24.6)$ \\
No & 10 & $6(60)$ & $4(40)$ \\
Chi-square & & 3.659 & 1.152 \\
p-value & & 0.056 & 0.283 \\
Total & 144 & $47(32.6)$ & $37(25.7)$ \\
\hline
\end{tabular}

\section{Discussion:}

In this study, an overall seroprevalence of $32.6 \%$ and $25.7 \%$ was reported for anti-HTLV IgG and IgM antibodies respectively in HIV-1 infected individuals in UITH, Ilorin. Fourteen percent of the study participants had both IgG and IgM antibodies to HTLV, which is an indication that this group has been recently infected with HTLV and are at the point of seroconversion. Only 16 participants with IgM antibodies to HTLV can be said to be recently infected among the participants recruited. This observation is not conclusive because there was lack of information on time of onset of HIV-1 and HTLV infection but we can suggest that HTLV infection acquired is a marker of high risk behavior that might be associated with exposures to HIV-1.

In our study, we discovered that higher percentage of the participants infected were females, with $33.6 \%$ and $26.9 \%$ of them having IgG and IgM antibodies to HTLV respectively. Although, the number of females recruited in this study was more than the males, this could be because there is more efficient transmission from men to women during sexual intercourse. The HTLV sero-prevalence among HIVinfected individuals in this study is higher than the prevalence reported in previous studies, and this may be adduced to the reluctance in adapting to behaviours that are less risky especially amongst those with HIV in Ilorin. Also, the high sero-prevalence rate may be as a result of the method employed in this study. Nasir et al. (13) reported an overall sero-prevalence of $4.9 \%$ for HIV-1/HTLV co-infection among ART naïve patients in Abuja. In Brazil, HTLV1 prevalence of $1.9 \%$ was reported in HIV-1 patients using the Polymerase Chain Reaction assay (14). Rego et al. (15) reported the prevalence of HTLV/HIV-1 co-infection to be $1.8 \%$ in KwaZulu-Natal, South Africa. In another study conducted in rural Guinea-Bissau among HIV-1 and HIV-2-infected women, overall HTLV-1 prevalence of $5.2 \%$ was reported (16). The difference is most likely due to the difference in the design, population and method of detection of HTLV. Molecular methods were used to confirm HTLV proviral DNA in the studies mentioned, whereas antibody detection was solely used in 
this study.

In our study, the highest prevalence of HTLV IgG and IgM antibodies was among age group 40-49 years. This was in contrast with Nasir et al. (13) study who reported highest prevalence of HTLV-1 among age group 21-30 years. This could be due to the fact that the population of those mostly recruited falls among this age group in our study. Also, there is a presumption that the accumulation of sexual exposures with age in women of this population might contribute to the results obtained in this study.

Thirty out of 37 patients with IgM antibodies to HTLV had CD4+ lymphocyte count more than 200 cells $/ \mathrm{mm}^{3}$ in our study, which is an indication that co-infected individuals may present with a seemingly normal CD4+ cell counts that may not correctly reflect the true immune status of the individual. We cannot interpret in clear terms that the seven individuals with CD4+ lymphocyte count less than 200 cells $/ \mathrm{mm}^{3}$ who produced IgM antibodies to HTLV is associated with HIV-1 immune status of the individuals. In this scenario the immune system will be incompetent to produce neutralizing antibodies since HIV-1 infection can also lead to extensive defects in the humoral arm of the immune system (17).

There are reports that CD4+ lymphocyte count cannot always be considered a reliable marker of immunological competence in HIV-1 infected people, especially in patients co-infected with $\operatorname{HTLV}(3,18,19)$. There was no significant association between CD4+ cell count in HTLV/HIV-1 coinfected patients compared to HIV-1 infected individuals $(p=0.163)$. CD4+ cell count is one of the important criteria used to determine eligibility for HAART in HIV-1-infected individuals especially in resource-limited settings nevertheless in the event of HTLV/HIV-1 coinfections, CD4 cell counts may not be reliable.

\section{Conclusion:}

Our findings in this study revealed that there is high seroprevalence of HTLV IgG and IgM among
HIV-1 sero-positive patients in UITH. The high rate of co-infection supports routine screening for HTLV-1/2 coinfection among HIV-1 infected individuals in Ilorin, Nigeria so that the purpose of HAART treatment and monitoring of patients to prevent progression to AIDS will not be aborted.

Treatment modality in individuals co-infected with HIV- 1 and HTLV-1/2 is recommended because these patients present normal or unexpectedly high CD4+ $T$ cell counts which does not account for the immunosuppression experienced.

\section{Competing interest:}

The authors have no competing interest to declare

\section{Funding:}

for this study

The authors receive no funding Acknowledgements:

The authors hereby acknowledge the assistance of Mr Olaolu Kehinde for his financial support and Mr. Dele Amodu of the Rotavirus Laboratory of the University of Ilorin Teaching Hospital for the assistance in running of the assay.

\section{References:}

1. Araujo, A., Sheehy, N., Takahashi, H., and Hall, W. W. Concomitant Infections with Human Immunodeficiency Virus Type-1 and Human T-Lymphotrophic Virus Types 1 and 2. In: Brogden, K. A., and Guthmiller, J. M. (eds.). Polymicrobial Diseases. ASM Press, Washington DC, 2002

2. Roy, U., Simpson, S. A., Mondal, S., Eloby-Childress, S., Winsor, E. L., and Beilke, M. A. Upregulation of HTLV-1 and HTLV-2 Expression by HIV-1 in-vitro. J Med Virol. 2008; 80(3): 494-500.

3. Mazanderani, A. F. H., and Ebrahim, O. Progressive HIV-1 infection in the presence of a raised CD4+count: HIV1/HTLV-1 co-infection. South Afr J HIV Med. 2013; 14(2): 92-94.

4. Oladipo, E. K., Akinpelu, O. O., Oladipo, A. A., Afolabi, A. Y., Popoola, B., Edowhorhu, G., and John, F. Human-T Lymphotrophic Virus 1 (HTLV-1) Among Blood Donors in Ogbomoso, Oyo State, 
Nigeria. Transl Med 2015; 5: 146. doi: 10.4172/2161-1025.1000146

5. Iyalla, C., Ejele, A. O., Okoh, D. A., and Igbigbi, E. Seroprevalence study of HTLV1 and 2 in prospective blood donors and pregnant women in Port Harcourt, Nigeria. Afr J Infect Dis. 2015; 9(2), 57-60.

6. Durojaiye, I., Akinsegun, A., Adedoyin, D., Sarah, A., Adewumi, A., Ebele, U., Olajumoke, O., Majeed, O., Akinola, D., and Olaitan, O. Seroprevalence of human $\mathrm{T}$ lymphotrophic virus antibodies among healthy blood donors at a tertiary centre in Lagos, Nigeria. Pan Afr Med J. 2014; 14 (17): 301.

7. Yuguda, S., Manga, M. M., Fowotade, A., Chukwuma, O. E., and Aken', O. Y. Seroprevalence of Human T-Cell Lymphoma/Leukemia Virus Type- 1 (HTLV-1) Antibodies among Blood Donors at Ibadan, Nigeria. J Hum Virol Retrovirol. 2017; 5 (5): 00169.

8. Okoye, A. E., Ibegbulam, O. G., Onoh, R. C., Ugwu, N. I., Anigbo, C. S., and Nonyelu, C. E. Seroprevalence of human T-cell lymphoma/leukemia virus type-1 (HTLV-1) antibodies among blood donors at Enugu, Nigeria. J Blood Med. 2015; 6: 31-36.

9. Brites, C., Alencar, R., Gusmão, R., Pedroso, C., Netto, E. M., and PedralSampalo, D. Co-infection with HTLV-1 is associated with a shorter survival time for HIV-1infected patients in Bahia, Brazil. AIDS. 2001; 15 (15): 2053

10. Araoye, M. O. Research Methodology with Statistics for Health and Social Science. Nathadex Publishers, Ilorin. 2003: 115129.

11. Akinleye, O. M., Olaniyan, J. A. T., Okoye, C. A., and Eke, C. F. Blood safety and prevalence of transfusion transmissible viral infection among Blood donors in Lagos, Nigeria. Int J Trop Med. 2013; 8 (5-6): 113-118.

12. World Health Organisation. Laboratory guidelines for enumerating CD4 T lymphocytes in the context of HIV1/AIDS. 2007:
13.

Nasir, I. A., Ahmad, E. A., Emeribe, A. U., Shehu, M. S., Medugu, J. T., and Babayo, A. Molecular Detection and Clinical Implications of HTLV-1 Infections among Antiretroviral TherapyNaïve HIV-1-1-Infected Individuals in Abuja, Nigeria. Virology (Auckl). 2015; 6: 17-23.

14. Galetto, L. R., Lunge, V. R., and Béria, J. $U$. Prevalence and risk factors for human $\mathrm{T}$ cell lymphotrophic virus infection in southern Brazilian HIV-1-positive patients. AIDS Res Human Retrovirol. 2014; 30 (9):907-911.

15. Rego, F. F. A., Alcantara, L. C. J., and Tulio de Oliveira. Human $T$ cell lymphotrophic virus type 1 (HTLV-) infection increases the CD4 count in human immunodeficiency virus type 1 (HIV-1) infected patients submitted to antiretroviral therapy (ART). Retrovirol. 2014; 11 (S1): 62 .

16. Holmgren, B., Da Silva, Z., Larsen, O., Vastrup, P., Andersson, S., and Aaby, P. Dual infections with HIV-1, HIV-2 and HTLV-I are more common in older women than men in Guinea-Bissau. AIDS. 2003; 17 (2): 241-253.

17. Moir, S., and Fauci, A. S. B cells in HIV-1 infection and disease. Nat Rev Immunol. 2009; 9 (4): 235-245.

18. Scapellato, P. G., Bottaro, E., and Rodriguez-Brieschke, M. T. CD4 cell count among HIV-1-infected patients with an AIDS-defining disease: higher count in patients co-infected than in those not co-infected with human T-cell lymphotrophic virus type I. J Acquir Immune Defic Syndr. 2003; 33: 279-280.

19. Gudo, E. S. Jr., Bhatt, N. B., Augusto, O., Semá, C., Savino, W., Ferreira, O. C. Jr., and Jani I. V. Performance of absolute CD4+count in predicting co-infection with human T-Lymphotrophic virus type 1 in antiretroviral-naive HIV-1infected patients. Int J STD AIDS. 2012; 23 (10): 717-23. 